А. П. ПОЛИВ' ЯНЧУК ${ }^{1}$, д-р техн. наук, проф., О. І. КАСЛІн ${ }^{2}$,

М. Ф. СМИРНИЙ ${ }^{1}$, д-р техн. наук, проф., О. П. СТРОКОВ ${ }^{3}$, д-р техн. наук, проф.,

\title{
О. О. СКУРІДІНА
}

${ }^{1}$ Харківський наџіональний університет міського господарства імені О.М. Бекетова

вул. Маршала Бажанова, 17, м. Харків, 61002, Україна

e-mail: apmail@meta.ua

${ }^{2}$ Національний технічний університет «Харківський політехнічний інститут»

вул. Кирпичова, 21, м. Харків, 61002, Україна

e-mail: dvs@kpi.kharkov.ua

${ }^{3}$ Класичний приватний університет

вул. Жуковського 70-б, м. Запоріжжя, 69002, Україна

e-mail: kpuinform@gmail.com

${ }^{4}$ Східноукраӥнський національний університет імені Володимира Даля

проспект Центральний, 59-а, м Сєвєродонецьк, 93400, Україна

e-mail: icd@snu.edu.ua

\section{ВПРОВАДЖЕННЯ КОМПЕНСАЩЙНОГО МЕТОДУ КОНТРОЛЮ ПРОБИ В УНІВЕРСАЛЬНИХ СИСТЕМАХ ЕКОЛОГІЧНОГО ДІАГНОСТУВАННЯ ДИЗЕЛІВ - МІКРОТУНЕЛЯХ}

Мета. Розробка, впровадження та підтвердження практичної придатності компенсаційного методу контролю газової проби в мікротунелях, який $\epsilon$ значно дешевшим ніж відомі аналоги, зокрема диференційний метод, що використовується у вимірювальній системі AVL SPC 472. Методи: Аналіз та синтез інформації, регресійний аналіз, експериментальні дослідження, розрахунковий експеримент. Результати. Розроблено заходи щодо впровадження недорогого компенсаційного методу контролю газових проб в універсальних системах екологічного діагностування дизелів - мікротунелях. Висновки. Обгрунтовано доцільність використання та експериментально підтверджено практичну придатність компенсаційного методу контролю проби, який в 5...8 разів дешевше відомого аналога - диференційного методу, реалізованого в мікротунелі AVL SPC 472, та передбачає застосування недорогих витратомірів 3 класом точності 1,5.

Ключові слова: дизель, відпрацьовані гази, газова проба, мікротунель, компенсаційний метод, диференційний метод, точність

Polivyanchuk A. P. ${ }^{1}$, Kaslin O. I. ${ }^{2}$, Smirny M. F. ${ }^{1}$, Strokov O. P. ${ }^{3}$, Skuridina O. O.

${ }^{1}$ O. M. Beketov National University of Urban Economy in Kharkiv

${ }^{2}$ National Technical University "Kharkiv Polytechnic Institute"

${ }^{3}$ Classic Private University

${ }^{4}$ Volodymyr Dahl East Ukrainian National University

INTRODUCTION OF THE COMPENSATORY METHOD OF GAS SAMPLE CONTROL IN UNIVERSAL SYSTEMS OF ECOLOGICAL DIAGNOSTICS OF DIESEL ENGINES - MICROTUNNELS

Purpose. The development, implementation and confirmation of the practical suitability of the compensatory method for monitoring a gas sample in microtunnels, which is significantly less expensive than the known analogs, in particular the differential method used in the AVL SPC 472 measuring system. Methods. Analysis and synthesis of information on methods for controlling gas samples, regression analysis in the construction of calibration dependences, experimental studies of the method under study, a calculated experiment in evaluating the accuracy of determining the dilution factor of a sample. Results. Measures have been developed to introduce an inexpensive compensatory method for controlling gas samples in universal systems for the ecological diagnosis of diesel engines - microtunnels: the method of calibrating the flowmeters of this method - standard narrowing devices, the method of indirect measurement of the mass flow rate of the sample in a microtunnel, the algorithm for regulating the flow rate of the sampled sample. Conclusions. Theoretically justified, the expediency of using the compensation method of sample control, which is $5 \ldots 8$ times cheaper than the known analogue - the differential method used in the microtunnel AVL SPC 472. It has been experimentally confirmed that, when implementing the compensation test method, inexpensive flow meters - standard tapering devices with a precision class of 1.5 provide the required accuracy of measurements of the dilution factor of exhaust gases by air with an error not exceeding the permissible value of $\pm 4 \%$ and can be used in universal ecological diagnostic systems diesels - microtonules.

Keywords: diesel, exhaust gases, gas sample, microtunnel, compensation method, differential method, accuracy

(С Полив’янчук А. П., Каслін О. І., Смирний М. Ф., Строков О. П., Скурідіна О. О., 2017

DOI: https://doi.org/10.26565/1992-4259-2017-17-09 
Поливянчук А. П. ${ }^{1}$ Каслин А. И. ${ }^{2}$, Смирный М. Ф. ${ }^{1}$, Строков А. П. ${ }^{3}$, Скуридина Е. А. ${ }^{4}$

${ }^{I}$ Харьковский наииональный университет городского хозяйства имени А.Н. Бекетова

${ }^{2}$ Национальный технический университет «Харьковский политехнический институт»

${ }^{3}$ Классический приватный университет

${ }^{4}$ Восточноукраинский национальный университет имени Владимира Даля

ВНЕДРЕНИЕ КОМПЕНСАЦИОННОГО МЕТОДА КОНТРОЛЯ ПРОБЫ В УНИВЕРСАЛЬНЫХ СИСТЕМАХ ЭКОЛОГИЧЕСКОГО ДИАГНОСТИРОВАНИЯ ДИЗЕЛЕЙ МИКРОТУННЕЛЯХ

Цель. Разработка, внедрение и подтверждение практической пригодности компенсационного метода контроля газовой пробы в микротуннелях, который имеет значительно меньшую стоимость чем аналоги, в частности дифференциальный метод, используемый в измерительной системе AVL SPC 472. Методы. Анализ и синтез информации, регрессионный анализ, экспериментальные исследования, расчетный эксперимент. Результаты. Разработаны мероприятия по внедрению недорогого компенсационного метода контроля газовых проб в универсальных системах екологического диагностирования дизелей - микротуннелях. Выводы. Обоснована целесообразность применения и експериментально подтверждена практическая пригодность компенсационного метода контроля пробы, который в 5..8 раз дешевле известного аналога - дифференциального метода, используемого в микротуннеле AVL SPC 472, и предусматривает применение недорогих расходомеров с классом точности 1,5 .

Ключевые слова: дизель, отработавшие газы, газовая проба, микротуннель, компенсационный метод, дифференциальный метод, точность

\section{Bcmyn}

Значний внесок в проблему забруднення атмосферного повітря міського середовища токсичними продуктами згоряння різних палив вносять пересувні джерела викидів забруднюючих речовин 3 дизельними силовими установками - автомобілі, автобуси, тепловози, трактори та ін. Для підвищення екологічної чистоти цих об'єктів проводять діагностування дизелів за нормованими показниками токсичності відпрацьованих газів (ВГ) з використанням спеціального обладнання та вимірювальних систем. Однією $з$ таких систем $є$ компактний універсальний вимірювальний комплекс 3 мікротунелем для контролю викидів твердих частинок (ТЧ) з ВГ дизелів різних типів [1-3]. В цій системі здійснюється імітація природного процесу потрапляння ТЧ у атмосферу шляхом розбавлення повітрям частки ВГ, відібраної з вихлопної труби дизеля, у спеціальному трубопроводі
- мікротунелі 3 діаметром $\sim 3$ см та довжиною $\sim 30$ см [4-6].

Актуальною задачею проектування сучасних мікротунелів $є$ вибір ефективного - точного і недорогого методу контролю проби ВГ, яка потрапляє від дизеля до трубопроводу розбавлення ВГ - тунелю. Цей метод $є$ непрямим оскільки безпосередній контроль проби ВГ ускладнюється іiі високою температурою - до $600{ }^{\circ} \mathrm{C}$, хімічною агресивністю та наявністю дизельних ТЧ. 3 метою вирішення цієї задачі авторами розроблено компенсаційний метод контролю проби ВГ, доведено його ефективність в результаті порівняння з відомим аналогом диференційним методом, який використовується мікротуннелі $A V L S P C 472[7,8]$ та експериментально підтверджено практичну придатність запропонованого методу в ході безмоторних випробувань вузла відбору газових проб мікротунеля.

\section{Об’єкт та методи досліджень}

Характеристика диференційного та альтернативного йому компенсаційного методів контролю проби. Контроль газової проби в мікротунелі передбачає непряме визначення масової витрати частки потоку ВГ $-G_{e x h}^{t}$, яка відбирається 3 вихлопної труби дизеля і потрапляє до розбавляючого тунелю для змішування 3 атмосферним повітрям (рис. 1).

За результатами визначення величини $G_{e x h}^{t}$ та масової витрати розбавлених ВГ у тунелі $-G_{t}$ встановлюється коефіцієнт розбавлення ВГ $-q$, який разом 3 температурою розбавлених ВГ контролюється відповідно до встановлених вимог:

$$
q=\frac{G_{t}}{G_{e x h}^{t}} .
$$

Згідно $з$ вимогами нормативних документів допустима похибка визначення коефіцієнта $q$ складає $\pm 4 \%[4,5]$. 


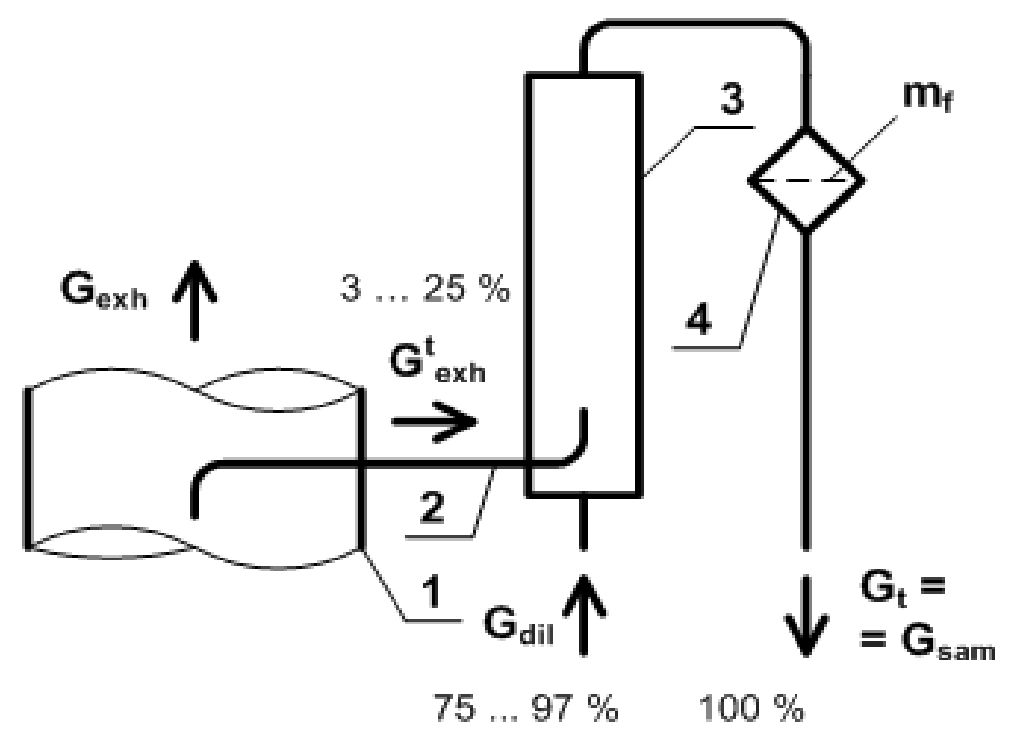

1 - вихлопна труба дизеля; 2 - трубопровід транспортування проби ВГ; 3 - трубопровід розбавлення ВГ - тунель; 4 - патрон з фільтром для відбору ТЧ

Рис. 1 - Принципова схема процесу відбору проб ВГ дизеля

При використанні диференційного методу контролю прорби, який реалізовано в мікротунелі $A V L S P C 472$, величина $G_{e x h}^{t}$ визначається як різниця масових витрат 2-х потоків: розбавлених ВГ $-G_{t}$ та розбавляючого повітря $-G_{d i l}$ (рис. 2 , а). відповідно до цього коефіцієнт $q$ визначається за формулою:

$$
q=\frac{G_{t}}{G_{t}-G_{d i l}} .
$$

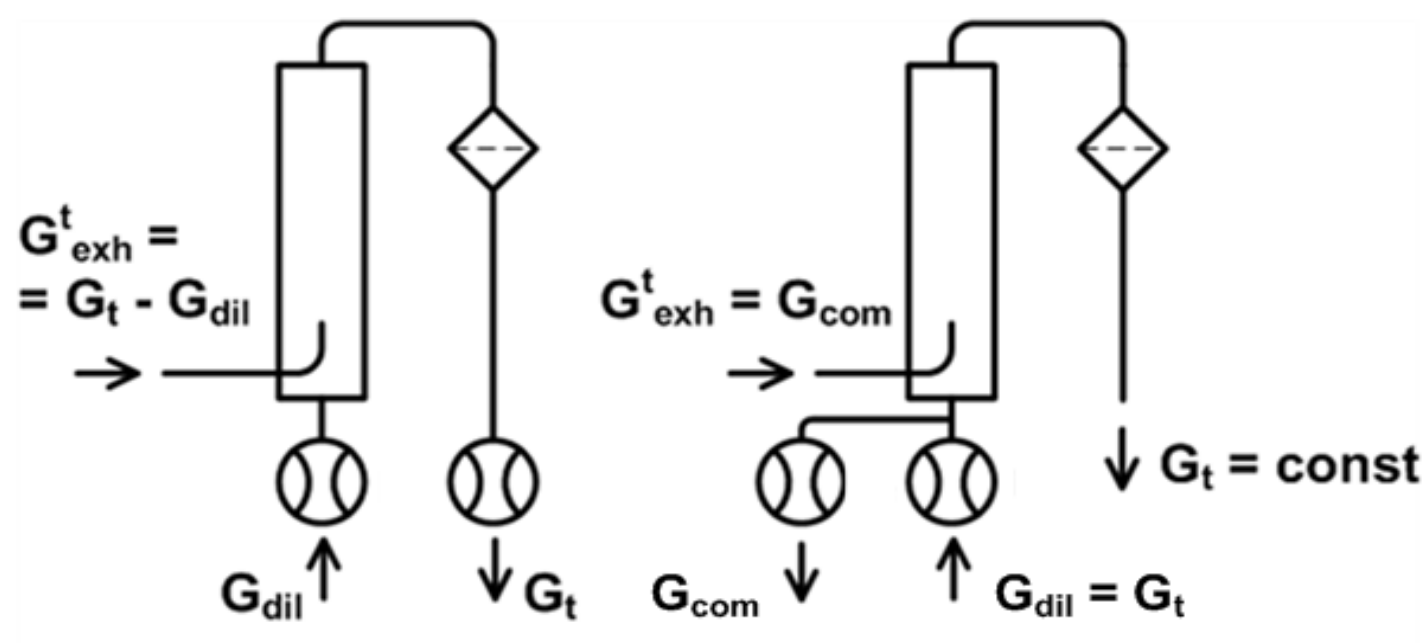

$\mathrm{a}$

a - диференційний метод контролю проби; б - компенсаційний метод контролю проби.

Рис. 2 - Принципові схеми різних методів контролю проби ВГ в мікротунелі

Для використання цього методу контролю величини $G_{e x h}^{t}$ i забезпечення потрібної точності визначення коефіцієнта $q$ потрібні високоточні вартісні прилади для вимірювань масових витрат $G_{t}$ та $G_{d i l} 3$ похибками, які складають $\pm 0,1 \ldots 0,2 \%$ $[9,10]$.
При використанні компенсаційного методу контролю прорби, який пропонується в якості альтернативи розглянутому методу, величина $G_{e x h}^{t}$ визначається як масова витрата потоку компенсованого повітря $G_{e x h}^{t}=G_{c o m}$, що відбирається від потоку розбавляючого повітря при умові підтрим- 
ки цього потоку на постійному рівні $G_{d i l}=$ $G_{t}=$ const (рис. 2,б). Коефіцієнт $q$ в цьому випадку визначається за формулою:

$$
q=\frac{G_{d i l}}{G_{\text {com }}} .
$$

При використанні цього методу потрібна точність визначення коефіцієнта $q$ забезпечується при використанні недорогих приладів для вимірювань масових витрат потоків $G_{c o m}$ та $G_{d i l} 3$ класом точності 1,5 [9,10]. До таких приладів відносяться стандартні звужуючі пристрої - нормальне сопло, колектор, діафрагма та ін., вартість яких у $5 \ldots 8$ разів менша ніж у витратомірів вимірювальної системи AVL SPC 472.

Таким чином використання компенсаційного методу контролю проби дозволяє зменшити вартість мікротунелів за рахунок використання недорогих приладів для вимірювання величини $G_{e x h}^{t}$ при забезпе- чені потрібної точності визначення коефіцієнту розбавлення ВГ повітрям.

Заходи щодо впровадження компенсаційного методу контролю проби розроблені з метою перевірки практичної придатності цього методу і складаються 3:

- методики калібрування витратомірів компенсаційного методу контролю проби;

- методики визначення масової витрати проби $G_{e x h}^{t}$ компенсаційним методом;

- алгоритму регулювання потоків $G_{t}$ та $G_{\text {com }}$

Ці заходи були реалізовані на базі безмоторного випробувального стенду 3 мінітунелем МТ-1, в якому для вимірювань масових витрат $G_{d i l}$ i $G_{c o m}$ використовувались стандартні звужуючі пристрої колектор і діафрагма, спроектовані у відповідності до встановлених вимог $[11,12]$.

\section{Результати та обговорення}

Методика калібрування витратомірів компенсаційного методу контролю проби передбачає встановлення регресійних залежностей коефіцієнтів витрат колектора $-\alpha_{k}$ та діафрагми $-\alpha_{d}$ від відповідних чисел Рейнольдса в робочих діапазонах варіювання цих величин: для колектору $\operatorname{Re}_{k} \cdot 10^{-3}=45 \ldots 67$, що відповідає $G_{t}=18 \ldots 26$ г/с; для діафрагми $-\operatorname{Re}_{d} \cdot 10^{-3}=1,9 \ldots 9,5$, що відповідає $G_{c o m}=1 \ldots 5$ г/с. Процедура калібрування вказаних витратомірів складається 3 наступних операцій:

1. Приєднання до кожного витрато-міру еталонного пристрою та штатної газодувки, яка забезпечує варіювання масової витрати потоку повітря у відповідному робочому діапазоні. В якості еталонних витратомірів використовуються газові лічильники об'ємного типу - РГ-100 для калібрування колектору та РГ-40 для калібрування діафрагми, які оснащені датчиками числа обертів роторів, температури та тиску; відносні похибки вимірювань масових витрат при цьому не перевищують $\pm 1 \%$.

2. Визначення контрольних точок для проведення вимірювань шляхом роподілу робочих діапазонів варіювання регуляторів масових витрат на елементарні інтервали.

3. Експериментальне визначення $\mathrm{y}$ контрольних точках параметрів: бараметричного тиску $-P_{a}$, температури $-t_{a}$ та відносної вологості $-\varphi_{a}$ навколишнього середовіща; розрідження на колекторі $-\Delta P_{k}$ та еталонної масової витрати $-G_{t 0}$; температури $-t_{d}$, статичного тиску $-P_{d}$, перепаду тиску $-\Delta P_{d}$ в діафрагмі та еталонної масової витрати $-G_{\text {com } 0}$.

4. Розрахунок для кожної контрольної точки параметрів: тиску $-P_{w p}$ та щільності - $\rho_{w p}$ насиченого водяного пару у повітрі: $\mathrm{P}_{\mathrm{wp}}=566+57,54 \cdot t_{a}+0,27 \cdot t_{a}^{2}+0,063 \cdot t_{a}^{3}$, Па,

$\rho_{\mathrm{up}}=\left(6,3+0,02 \cdot t_{a}+0,0264 \cdot t_{a}^{2}\right) \cdot 10^{-3}, \mathrm{~K} / \mathrm{M}^{3}$;

кінематичних в'язкостей повітря в колекторі та діафрагмі $-v_{k} \mathrm{i} v_{d}$, які відповідають значенням абсолютних температур повітря $T_{a}$ i $T_{d}: T_{a}=t_{a}+273,15$, $T_{d}=t_{d}+273,15$; щільності повітря $\mathrm{y}$ навколишньому середовищі $-\rho_{a}$ та $\mathrm{y}$ діафрагмі $-\rho_{d}$ :

$$
\begin{aligned}
\rho_{\mathrm{a}}=A \cdot \frac{P_{a}-\frac{\varphi a}{100} \cdot P_{w p}}{T_{a}}+\frac{\varphi a}{100} \cdot \rho_{w p}, \quad(6) \\
\rho_{\mathrm{d}}=A \cdot \frac{\left(P_{a}+P_{d}\right)-\frac{\varphi a}{100} \cdot P_{w p}}{T_{d}}+\frac{\varphi a}{100} \cdot \rho_{w p}, \quad(7) \\
\text { де } A=\left(\rho_{0} \cdot T_{0}\right) /\left(P_{0} \cdot K\right)=3,487 \cdot 10^{-3}-\text { конс- }
\end{aligned}
$$
танта, $K=0,9996$ - коефіцієнт стискуваності повітря; коефіцієнтів, які врахову-ють зменшення щільності повітря при про- 
ходженні через колектор $-\varepsilon_{k}$ та діафрагму $\varepsilon_{d}$ :

$$
\begin{gathered}
\varepsilon_{k}=\left(\frac{\frac{k}{k-1} \cdot \Psi^{\frac{2}{k}} \cdot\left(1-\Psi^{\frac{k-1}{k}}\right)}{\left.\frac{\Delta P_{k}}{P_{a}}\right),}\right. \\
\varepsilon_{d}=1-0,424 \cdot \frac{\Delta P_{d}}{\left(P_{a}+P_{d}\right) \cdot K} .
\end{gathered}
$$

5. Визначення для кожної контрольної точки відповідних значень числа Рейнольдса та коефіцієнта витрати:

для колектора:

$$
\operatorname{Re}_{k}=\frac{4 \cdot G_{t 0}}{\pi \cdot v_{k} \cdot \rho_{k} \cdot D_{k}},
$$

де $D_{k}=26,21 \cdot 10^{-3} \mathrm{M}-$ діаметр отвору колектора;

$$
\alpha_{k}=\frac{G_{t 0}}{\varepsilon_{k} \cdot \frac{\pi \cdot D_{k}}{4} \cdot\left(2 \cdot \Delta P_{k} \cdot \rho_{a}\right)^{0,5}},
$$

для діафрагми:

$$
\operatorname{Re}_{d}=\frac{4 \cdot G_{c o m 0}}{\pi \cdot v_{d} \cdot \rho_{d} \cdot D_{d}}
$$

де $D_{d}=18,15 \cdot 10^{-3} \mathrm{M}-$ діаметр трубопроводу, в якому встановлено діафрагму;

$$
\alpha_{d}=\frac{G_{\text {com } 0}}{\varepsilon_{d} \cdot \frac{\pi \cdot d_{d}}{4} \cdot\left(2 \cdot \Delta P_{d} \cdot \rho_{d}\right)^{0,5}},
$$

де $d_{d}=3,04 \cdot 10^{-3} \mathrm{M}-$ діаметр отвору діафрагми.

6. Встановлення за допомогою методу найменших квадратів залежностей коефіцієнтів витрат $\alpha_{k}$ та $\alpha_{d}$ від відповідних значень $\operatorname{Re}_{k}$ та $\operatorname{Re}_{d}$.

7. Оцінювання точності калібрування витратомірів за такими показниками, як

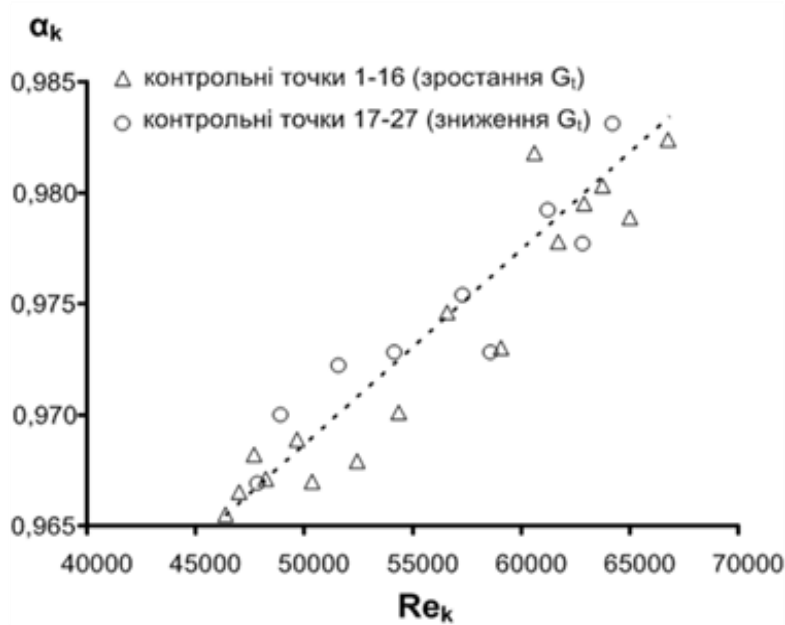

Рис. 3 - Калібрувальні характеристика колектора і діафрагми довірчі інтервали $-\Delta \alpha_{k}$ i $\Delta \alpha_{d}$ та відносні похибки $-\delta \alpha_{k}$ i $\delta \alpha_{d}$ :

$$
\Delta \alpha_{i}= \pm t_{0,95, f i} \cdot S_{\alpha i}
$$

де $i$ - індекс, що вказує на тип витратоміру $-k$ або $d ; t_{0,95, f i}$ - коефіцієнт Стьюдента при довірчій вірогідності 0,95 та кількості ступенів свободи $-f_{i}=n-1$ ( $n-$ кількість контрольних точок); $S_{\alpha i}-$ середньоквадратичне відхилення коефіцієнту витрати $\alpha_{i}$ :

$$
S_{\alpha i}=\left(\frac{\sum_{j=1}^{n}\left(\alpha_{i j}^{a}-\alpha_{i j}\right)^{2}}{n-2}\right)^{0,5},
$$

де $j$ - індекс контрольної точки; $\alpha_{i j}^{a}-$ розрахункове значення коефіцієнту $\alpha_{i}$ в $j$-й точці; $\alpha_{i j}-$ експериментальне значення коефіцієнту $\alpha_{i}$ в $j$-й точці;

$$
\delta \alpha_{i}=\frac{\Delta \alpha_{i}}{\bar{\alpha}_{i}} \cdot 100 \%
$$

де $\bar{\alpha}_{i}$ - середне значення коефіцієнту $\alpha_{i}$ у відповідному рабочому діапазоні.

Результати калібрування витратомірів компенсаційного методу за приведеним алгоритмом показали наступне (рис. 3):

1) регресійні залежності коефіцієнтів витрат колектора і діафрагми від відповідних значень числа $\operatorname{Re}$ мають вигляд поліномів 1-го порядку:

$$
\begin{gathered}
\alpha_{k}=0,9247 \cdot \operatorname{Re}_{k}+8,28 \cdot 10^{-7}, \\
\alpha_{d}=0,6612 \cdot \operatorname{Re}_{d}+7,05 \cdot 10^{-7} ;
\end{gathered}
$$

2) довірчі інтервали визначених коефіцієнтів витрат складають:

$$
\alpha_{k}= \pm 0,0065\left(S_{\alpha k}=0,0038, t_{0,95 ; 25}=1,708,\right.
$$

$$
n=27) \text {; }
$$

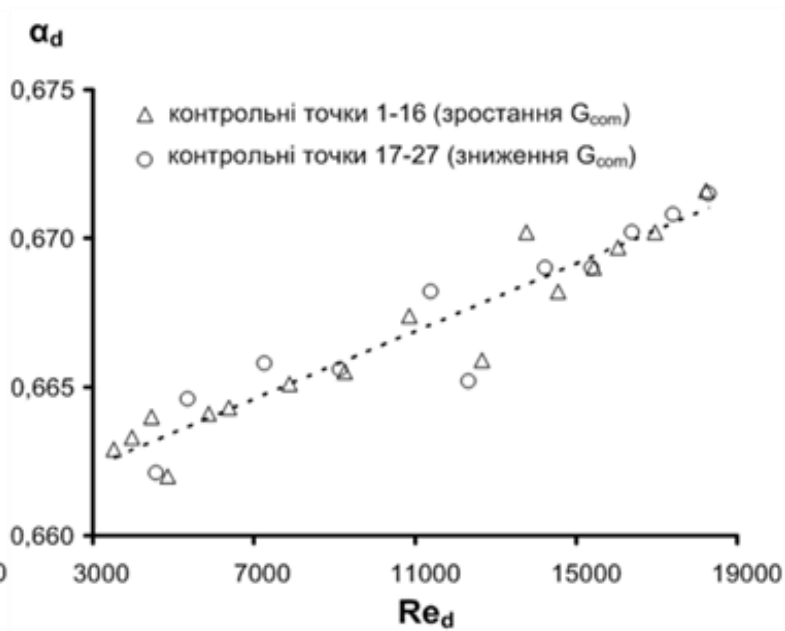




$$
\begin{gathered}
\alpha_{d}= \pm 0,0028\left(S_{\alpha d}=0,0016, t_{0,95 ; 25}=1,708,\right. \\
n=27) ;
\end{gathered}
$$

3) середні значення коефіцієнтів $\alpha_{k}$ i $\alpha_{d}$ у робочих діапазонах варіювання відповідних чисел Re складають:

$$
\begin{aligned}
& \bar{\alpha}_{k}=0,9745 ; \\
& \bar{\alpha}_{d}=0,6672 ;
\end{aligned}
$$

4) відносні похибки визначення величин $\alpha_{k}, \alpha_{d}$, встановлені за допомогою формули (14), мають значення: $\delta \alpha_{k}= \pm 0,67 \%$; $\delta \alpha_{d}= \pm 0,41 \%$.

Методика визначення величини масової витрати проби $G_{e x h}^{t}$ компенсаційним методом передбачає послідовне виконання наступних операцій.

1. Пряме вимірювання за допомогою відповідних датчиків величин: параметрів навколишнього середовища $-P_{a}, t_{a}$ та $\varphi_{a}$; розрідження на колекторі $-\Delta P_{k}$; параметрів газового потоку, що протікає в діафрагмі $t_{d}, P_{d}, \Delta P_{d}$; тиску $-P_{w p}$ та щільності $-\rho_{w p}$ насиченого пару;

2. Обчислення величин: $P_{w p}$ та $\rho_{w p}$ (за допомогою формул ((4) i (5)); $v_{k}$ та $v_{d} ; \rho_{a}$ та $\rho_{d}$ (за допомогою формул ((6) i (7)); $\varepsilon_{k}$ та $\varepsilon_{d}$ (за допомогою формул ((8) і (9));

3. Визначення початкових значень масових витрат потоку у тунелі $-G^{1}$ та компенсаційного потоку $-G_{\text {сот }}^{1}$ :

$$
G_{t}^{1}=\bar{\alpha}_{k} \cdot \varepsilon_{k} \cdot \frac{\pi \cdot D_{k}}{4} \cdot\left(2 \cdot \Delta P_{k} \cdot \rho_{a}\right)^{0,5},
$$

$$
G_{c o m}^{1}=\bar{\alpha}_{d} \cdot \varepsilon_{d} \cdot \frac{\pi \cdot d_{d}}{4} \cdot\left(2 \cdot \Delta P_{d} \cdot \rho_{d}\right)^{0,5} .
$$

4. Розрахунок величин $\operatorname{Re}_{k}$ та $\operatorname{Re}_{d}$ за допомогою формул (10) та (12), в які замість $G_{t 0}$ та $G_{c o m 0}$ підставляються значення $G_{t}^{1}$ та $G^{1}$ com.

5. Визнеачення уточнених значень коефіцієнтів $\alpha_{k}$ та $\alpha_{d}$ за допомогою калібрувальних залежностей (15) та (16).

6. Встановлення уточнених значень масових витрат потоку у тунелі та компенсаційного потоку:

$$
G_{t}=G_{k}^{1} \cdot \frac{\alpha_{k}}{\bar{\alpha}_{k}}, G_{c o m}=G_{c o m}^{1} \cdot \frac{\alpha_{d}}{\bar{\alpha}_{d}} .
$$

Алгоритм регулювання потоків $\mathbf{G}_{\mathbf{t}}$

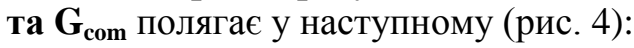

- при закритих клапанах 4 i 7 газодув-кою об'ємного типу 11 створюється масова витрата $G_{t}$ та підтримується постійною протягом всього циклу або режиму випробувань; контроль даної величини здійснюється витратоміром 12, а іï регулювання (методом перепустки частки потоку) - клапаном 13; постійність масової витрати $G_{t}$ забезпечується типом газодувки та підтримкою на заданих рівнях температури (регулюється теплообмінником 83 точністю \pm 1 ${ }^{\circ} \mathrm{C}$ ) та статичного тиску (регулюється клапаном 10 з точністю $\pm 0,1$ кПа) газового потоку, який вона створює;
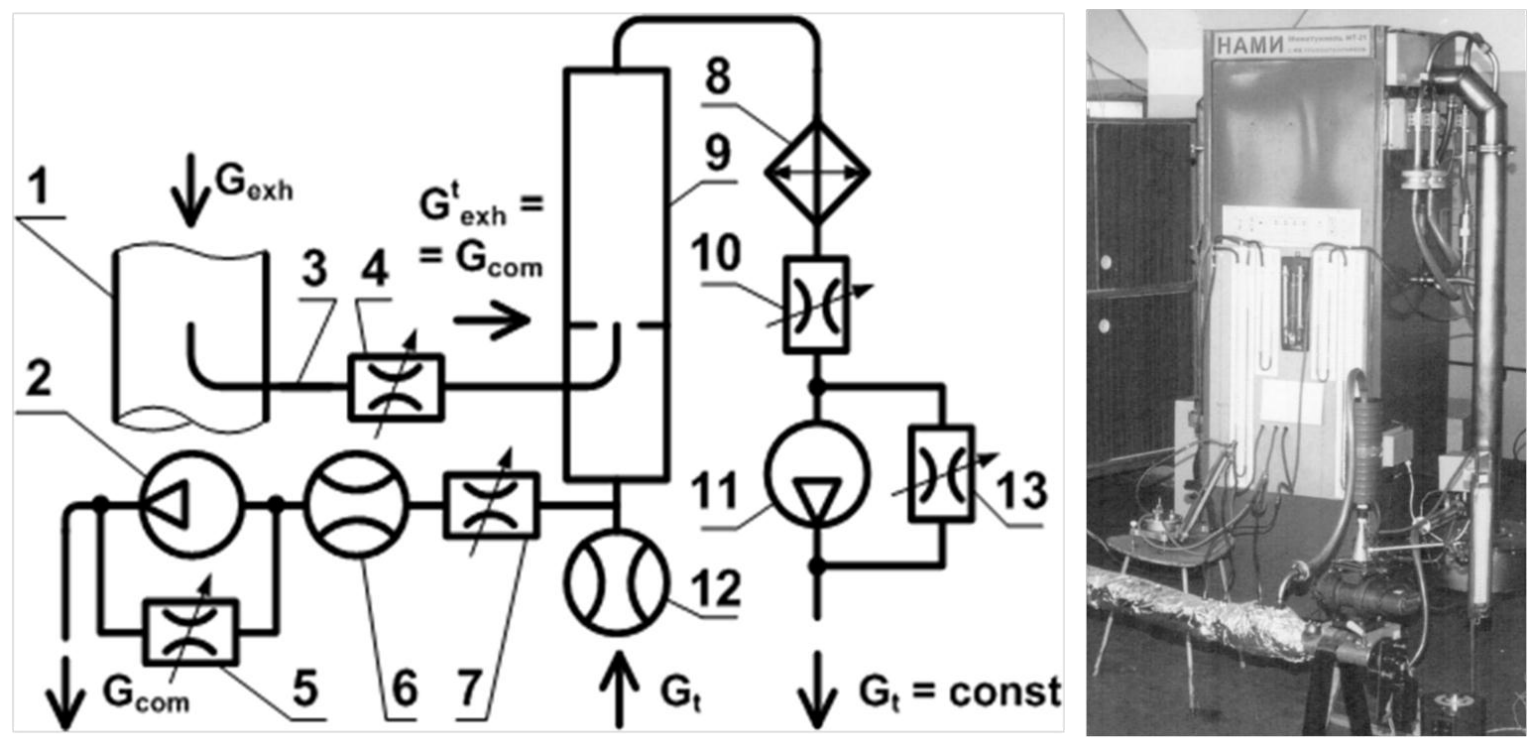

1 - вихлопна труба; 2 - штатні газодувки;3 - трубопровід транспор-тування проби; 4, 5, 7, 10 і 13 регулюючі клапани; 6, 12 - витратоміри; 8 - теплообмінник; 9 - розбавляючий тунель

Рис. 4 - Принципова схема та загальний вигляд безмоторного випробувального стенду з мінітунелем МТ-1 для відпрацювання компенсаційного методу контролю проби 
- відкривається клапан 7 та та газодувкою 2 створюється потрібна масова витрата компенсаційного потоку $G_{\text {com }}$; контроль цієї величини здійснюється витратоміром 6, а іiі регулювання (методом перепустки частини потоку) - клапаном 5;

- відкривається клапан 4 і за рахунок перепаду статичних тисків між вихлопною трубою та трубопроводом розбавлення ВГ у тунель потрапляє частка ВГ 3 масовою витратою $G_{e x h}^{t} ;$ при цьому клапан 4 переводиться у таке положення, при якому масова витрата потоку через витратомір 12 складає $G_{t}$; це забезпечує рівність масових витрат $G_{c o m}$ та $G_{\text {exh }}^{t}$, що підтверджується рівнянням матеріального балансу потоків, які протікають у тунелі:

$$
\begin{array}{ccc}
G_{t}^{(\text {газодукка })}+G_{\text {com }}=G_{\mathrm{t}}^{(\text {колектор })}+G_{\text {exh }}^{t} \cdot \\
\text { Ліва частина цього рівняння }
\end{array}
$$
відображає суму потоків, які потрапляють у тунель, права частина - які витікають 3 нього.

\section{Експериментальне оцінювання точності компенсаційного методу конт-}

ролю проби. В трубопроводі транспортування проби 3 між пробовідбірником та регулюючим клапаном 4 було встановлено контрольний витратомір - газовий лічильник РГ-40, який контролював масову витрату проби, що відбиралася i потрапляла до тунелю $-G_{\text {exh }}^{t} 3$ відносною похибкою, що не перевищувала $\pm 1 \%$.

Проведено 3 серії випробувань, в ході яких масова витрата $G_{t}$ (що створювалась газодувкою 11, регулювалась клапаном 13 та вимірювалась колектором 12) підпримувалась постійною на заданому рівні - 24 г/c, а масова витрата $G_{\text {сот }}$ (що створювалась газодувкою 2, регулювалась клапаном 2 та вимірювалась діафрагмою 6) варіювалась в рандомізованому порядку на 5 рівнях: 1,4, 2, 3, 4 та 5 г/с (відповідні обємні витрати складали: 70, 100, 150, 200 та 250 лн/хв).

За результатами випробувань визначено відносні відхилення масової витрати потоку в тунелі від заданого рівня $-\delta G_{t}$ та відносну похибку вимірювань масової витрати проби, яка відбиралася - $\delta G_{e x h}^{t}$ (рис. 5).

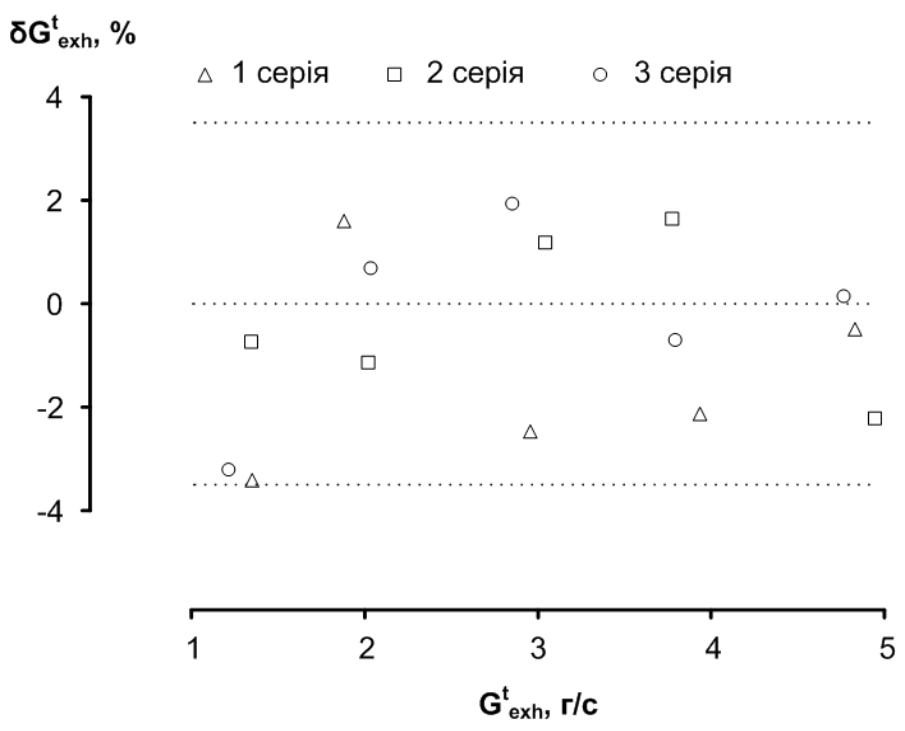

Рис. 5 - Відносна похибка вимірювань масової витрати $G_{e x h}^{t}$ компенсаційним методом

Отримані результати довели ефективність запропонованого методу вимірювань величини $G_{e x h}^{t}-$ у всьому діапазоні варіювання масової витрати $G_{c o m}$ відносна похибка $\delta G_{\text {exh }}^{t}$ не перевищує допустимого значення - 3,5\% (при цьому відхилення масової витрати $G_{t}$ від заданого рівня не перевищують $\pm 0,5 \%$ ).

\section{Висновки}

1. Запропоновано при контролі небезпечного забруднювача атмосфери міського середо- вища - дизельних твердих частинок використовувати в мікротунелях компенса- ційний метод контролю проби, який у 5..8 разів дешевше відомого аналога - диференційного метода, що використовується у мікротунелі AVL SPC 472. 
2. Експериментально підтверджено, що при реалізації компенсаційного методу контролю проби недорогі витратоміри стандартні звужуючі пристрої 3 класом точності 1,5 забезпечують потрібну точність вимірювань коефіцієнта розбавлення від- працьованих газів повітрям 3 похибкою, яка не перевищує допустимої величини $- \pm 4 \%$ та можуть використовуватись в універсальних системах екологічного діагностування дизелів - мікротунелях.

\section{Лimepamypa}

1. Polivyanchuk A. Improving the efficiency of emission control dispersed particles from diesel exhaust gases. Вісник Харківського нащіонального університету ім. Каразіна. Серія «Екологія». 2014. №1140, вип. 11. C. 83-88.

2. Polivyanchuk A., Parsadanov I. Experimental verification of microtunnel MKT-2 on the brake stand autotractor diesel engine . Industrial technology and engineering. Republic of Kazakhstan. 2015. №2 (15). P. $11-16$.

3. Поливянчук А.П. Повышение эффективности систем экологического диагностирования дизельних силових установок - туннелей . Людина та довкілля. Проблеми неоекології. 2016. № 3-4 (26). С. 132140.

4. Regulation No 49. Revision 6. Uniform provision concerning the approval of compression ignition (C.I.) and natural gas (NG) engines as well as positiveignition (P.I.) engines fuelled with liquefied petroleum gas (LPG) and vehicles equipped with C.I. and NG engines and P.I. engines fuelled with LPG, with regard to the emissions of pollutants by the engine. / United Nations Economic and Social Council Economic Commission for Europe Inland Transport Committee Working Party on the Construction of Vehicles. // E/ECE/TRANS/505, 2013. $434 \mathrm{p}$.

5. Regulation № 96. Revision 3. Uniform provision concerning the approval of compression ignition (C.I.) engines to be installed in agricultural and forestry tractors with regard to the emissions of pollutants by the engine. E/ECE/TRANS/505. 2014. 416 p.

6. ISO 8178-1: 2017. Reciprocating internal combustion engines. Exhaust emission measurement. Part 1: Testbed measurement of gaseous and particulate exhaust emissions, 2017. $150 \mathrm{p}$.

7. Smart Sampler PC SPC 472. PC program for SPC 472 control. AVL, List GmbH Graz, 1993. - 76 p.

8. Lianga Z., Tiana J., Rezaeia S., Zhanga Y. Investigation of SVOC nanoparticle emission from light duty diesel engine using GC $\times \mathrm{GC}-\mathrm{ToF}-\mathrm{MS}$. School of Mechanical Engineering, University of Birmingham. 2015. $31 \mathrm{p}$.

9. Поливянчук А., Игнатов О. Оценка эффективности компенсационного способа измерения массового расхода отработавших газов дизеля в микротуннеле. Прикладна екологія. 2009.№ 1(5). С 149-154.

10. Поливянчук А.П. Сравнительный анализ дифференциального и компенсационного способов измерения массового расхода отработавших газов дизеля в микротуннеле. Двигатели внутреннего сгорания. 2011. №2. С. 123-126.

11. Ханженков В.И. Аэродинамические характеристики коллекторов. Промышленная аэродинамика, №4. - М.: Изд-во ЦАГИ, 1953. С.45-62.

12. РД 50-213-80. Правила измерения расхода газов и жидкостей стандартными сужающими устройствами. М.: Изд-во стандартов, 1982. $319 \mathrm{c}$.

\section{References}

1. Polivyanchuk, A. (2014). Improving the efficiency of emission control dispersed particles from diesel exhaust gases. Visnyk of V. N.Karazin. Kharkiv National University of Series «Ecology», 11(1140), 83-88. [in English].

2. Polivyanchuk, A., Parsadanov, I. (2015). Experimental verification of microtunnel MKT-2 on the brake stand autotractor diesel engine . Industrial technology and engineering. Republic of Kazakhstan, 2(15), 11-16. [in English].

3. Polivyanchuk, A., Skurydyna, A. Kaslyn, I. (2016). Povyshenie ehffektivnosti sistem ehkologicheskogo diagnostirovaniya dizel'nih silovih ustanovok - tunnelej. [Increasing the effectiveness of environmental diagnostic systems for diesel power plants - tunnels]. Man and the environment. Issues of neoecology, 34(26), 132-140. [in Russian].

4. Regulation No 49. Revision 6 (2013). Uniform provision concerning the approval of compression ignition (C.I.) and natural gas (NG) engines as well as positiveignition (P.I.) engines fuelled with liquefied petroleum gas (LPG) and vehicles equipped with C.I. and NG engines and P.I. engines fuelled with LPG, with regard to the emissions of pollutants by the engine. United Nations Economic and Social Council Economic Commission for Europe Inland Transport Committee Working Party on the Construction of Vehicles. E/ECE/TRANS/505, 434. 
5. Regulation № 96. Revision 3. (2014). Uniform provision concerning the approval of compression ignition (C.I.) engines to be installed in agricultural and forestry tractors with regard to the emissions of pollutants by the engine. E/ECE/TRANS/505, 416.

6. ISO 8178-1: 2017. (2017). Reciprocating internal combustion engines. Exhaust emission measurement. Part 1: Test-bed measurement of gaseous and particulate exhaust emissions, 150.

7. Smart Sampler PC SPC 472. (1993). PC program for SPC 472 control. AVL, List GmbH Graz, 76.

8. Lianga, Z., Tiana, J., Rezaeia, S., Zhanga, Y. (2015). Investigation of SVOC nanoparticle emission from light duty diesel engine using GC $\times$ GC-ToF-MS. School of Mechanical Engineering. University of Birmingham, 31. [in English].

9. Polivyanchuk, A., Ignatov, O. (2009). Evaluation of the efficiency of the compensatory method for measuring the mass flow rate of exhaust gases of a diesel engine in a microtunnel. [Ocenka ehffektivnosti kompensacionnogo sposoba izmereniya massovogo raskhoda otrabotavshih gazov dizelya $\mathrm{v}$ mikrotunnele]. Applied ecology. Collection of scientific works of the Volodymyr Dahl East Ukrainian national university, 1(5), 149-154. [in Russian].

10. Polivyanchuk, A. (2011). Comparative analysis of differential and compensating methods for measuring the mass flow rate of exhaust gases of a diesel engine in a microtunnel. [Sravnitel'nyj analiz differencial'nogo i kompensacionnogo sposobov izmereniya massovogo raskhoda otrabotavshih gazov dizelya v mikrotunnele]. Internal combustion engines, 2, 123-126. [in Russian].

11. Hanzhenkov, V. (1953). Aerodynamic characteristics of collectors. [Aehrodinamicheskie harakteristiki kollektorov]. Industrial aerodynamics, 4, 45-62. [in Russian].

12. RD 50-213-80. (1982). Rules for measuring the flow of gases and liquids by standard narrowing devices. [Pravila izmereniya raskhoda gazov i zhidkostej standartnymi suzhayushchimi ustrojstvami]. Moscow: Standards Publishing House, 319. [in Russian]. 